\title{
Role of Fosinopril and Valsartan on Klotho Gene Expression Induced by Angiotensin II in Rat Renal Tubular Epithelial Cells
}

\author{
Q. Zhou S. Lin R. Tang P. Veeraragoo W. Peng R. Wu \\ Department of Nephrology, Xiangya Hospital, Central South University, Changsha, PR China
}

Key Words

Klotho $\cdot$ NRK-52E $\cdot$ Fosinopril $\cdot$ Valsartan

\begin{abstract}
Background/Aims: Klotho gene, a new anti-aging gene, is mainly expressed in the kidney tubules. Several studies have found the relationship between klotho and emergence and development of renal diseases. This study set out to explore the role of fosinopril (Fos) and valsartan (Val) on klotho expression induced by angiotensin II (Ang II) in rat renal tubular epithelial cells (NRK-52E). Methods: NRK-52E cells were divided into five groups according to the treatment of Ang II, Fos and Val. Transforming growth factor- $\beta_{1}\left(\right.$ TGF- $\left.\beta_{1}\right)$, p38, phospho-p38 (p-p38), p53, and Sp1 protein expression were determined by immunohistochemical and Western blotting analysis. Klotho expression was detected by reverse transcription-polymerase chain reaction and Western blotting analysis. Results: Ang II upregulated TGF- $\beta_{1}$, p-p38 and p53 expression, and inhibited Sp1 and klotho expression in NRK$52 \mathrm{E}$ cells. After the intervention of Fos and/or Val, TGF- $\beta_{1}$, p-p38 and p53 expression were downregulated, Sp1 and klotho expression were upregulated. TGF- $\beta_{1}$ and p53, Sp1 and klotho expression exhibited a positive linear correlation, respectively. Conclusion: We conclude that Fos and Val have a protective role in Ang II-induced renal damage, and it may be through mechanism of inhibiting TGF- $\beta_{1}$, p-p38 and p53 expression, thus upregulating $\mathrm{Sp} 1$ and klotho expression.
\end{abstract}

Copyright $\odot 2010$ S. Karger AG, Basel

\section{Introduction}

Klotho gene, a new anti-aging gene, is expressed predominantly in the kidney and choroid plexus, significantly in renal tubular epithelial cells [1]. Its deletion in mice results in phenotypes that resemble human aging, including shortened life span, arteriosclerosis, ectopic calcification, skin atrophy, osteoporosis, pulmonary emphysema and infertility [2]. These features resemble complications of patients with chronic renal failure. Recent studies have shown the association of klotho gene and renal diseases including hypertensive renal damage, acute renal failure, Institute of Cancer Research (ICR)derived glomerulonephritis, renal cell carcinoma, chronic renal failure and abnormalities in calcium and phosphorus metabolism [3-8], suggesting that the reduction of renal klotho gene expression is associated with the emergence and development of the pathological process of renal diseases. At present, however, little is known about the effects and mechanisms of renal klotho gene expression in renal diseases.

Numerous studies have shown that the renin-angiotensin system (RAS) plays a pivotal role in the progression of renal diseases, and angiotensin II (Ang II) is the main effector $[9,10]$. Blockade of the RAS with angiotensin-converting enzyme inhibitors (ACEI) and/or angiotensin type 1 (AT1) receptor blockers is currently the most potential measure to interfere with Ang II-mediated renal damage, and can abrogate progression of renal dis-

\section{KARGER}

Fax +41613061234 E-Mail karger@karger.ch www.karger.com (c) 2010 S. Karger AG, Basel

$1420-4096 / 10 / 0333-0186 \$ 26.00 / 0$

Accessible online at:

www.karger.com $/ \mathrm{kbr}$
Qiao-Ling Zhou

Department of Nephrology, Xiangya Hospita

Central South University, Changsha, Hunan 410008 (PR China)

Tel. +86731 8432 7238, Fax +8673182136349

E-Mail tangrbsoon@yahoo.com.cn 
eases in part independent of reduction in systemic blood pressure. Therefore, in the present study, we adopted rat renal tubular epithelial cells (NRK-52E) stimulated by Ang II in vitro and used drug intervention including an ACEI, fosinopril (Fos) and/or an AT1 receptor blocker, valsartan (Val), to investigate the possible physiological role of klotho gene in Ang II-induced renal damage.

\section{Methods}

\section{Rat Renal Tubular Epithelial Cell Culture}

NRK-52E cells were kindly gifted by Dr. Xue-qing Yu (Department of Nephrology, First Affiliated Hospital, Zhong Shan University, Guangzhou, China) and cultured in DMEM supplemented with $10 \%$ FBS. Cells, merged to $80 \%$ of the dish, were cultured in media agents after pretreatment with non-FBS DMEM for $12 \mathrm{~h}$. Five groups, control, Ang II $\left(10^{-7} \mathrm{~mol} / \mathrm{l}\right)$, Ang II $\left(10^{-7} \mathrm{~mol} / \mathrm{l}\right)$ + Fos $\left(10^{-5} \mathrm{~mol} / \mathrm{l}\right)$, Ang II $\left(10^{-7} \mathrm{~mol} / \mathrm{l}\right)+\mathrm{Val}\left(10^{-5} \mathrm{~mol} / \mathrm{l}\right)$ and Ang II $\left(10^{-7} \mathrm{~mol} / \mathrm{l}\right)+$ Fos $\left(10^{-5} \mathrm{~mol} / \mathrm{l}\right)+\mathrm{Val}\left(10^{-5} \mathrm{~mol} / \mathrm{l}\right)$, were cultured for $24 \mathrm{~h}$.

\section{Immunohistochemical Analysis for Transforming Growth}

Factor- $\beta_{1}\left(T G F-\beta_{1}\right), p 38$, Phospho-p38 (p-p38), p53 and Sp1

Cells cultured on slides for $24 \mathrm{~h}$ in view of immunohistochemical analysis were fixed with $10 \%$ formalin. A commercial SABC kit (Wuhan Boster Biological Technology Co. Ltd., China) was used. Briefly, cells were incubated with the following solutions: (1) $3 \% \mathrm{H}_{2} \mathrm{O}_{2}$ for $15 \mathrm{~min}$ to quench endogenous peroxidase activity; (2) $10 \%$ non-immunized serum to reduce non-specific binding for $30 \mathrm{~min}$ at $37^{\circ} \mathrm{C}$; (3) primary specific rabbit polyclonal antibody against TGF- $\beta_{1}, \mathrm{p} 38, \mathrm{p}-\mathrm{p} 38$, p53 and mouse polyclonal antibody against $\mathrm{Sp} 1$ (the ratios of concentration were all 1:150) solution overnight at $4^{\circ} \mathrm{C}$; (4) the slices were incubated with biotinylated secondary antibody against rabbit or mouse $1.5 \mathrm{~h}$ at $37^{\circ} \mathrm{C}$; (5) $\mathrm{SABC}$ reagent solution for $30 \mathrm{~min}$ at $37^{\circ} \mathrm{C}$; (6) incubated with streptavidin peroxidase until the desired stain intensity was seen at $37^{\circ} \mathrm{C}$, and (7) dehydrated through an alcohol series and mounted. All the solutions were diluted by PBS and the slices were washed 3 times (each for $3 \mathrm{~min}$ ) after each step. Brown and yellow colors in cytoplasm indicated positive results for TGF- $\beta_{1}$, p 38 and p-p38 expression, and in the nucleus for p53 and Sp1 expression. Three randomly selected fields of view under the microscope $(\times 400)$ were chosen as samples to detect the expression levels of protein; a positive signal was automatically semiqualified using the absorbance $(A)$ value of positive signaling by a pathology image analysis system (PIPS-2000).

Western Blotting Analysis for TGF- $\beta_{1}, p 38, p-p 38, p 53$, Sp1 and Klotho

The first step was collecting the harvested cells with $10 \mu$ lysis buffer $(2 \times$ SDS $)$ per $10^{6}$ cells. All the protein samples were boiled for $5 \mathrm{~min}$ and each containing $50 \mu \mathrm{g}$ protein was loaded onto a $12.5 \%$ SDS-PAGE gel, run and electroblotted onto nitrocellulose filters. Blots were blocked in 5\% non-fat milk in PBS for $2 \mathrm{~h}$. The membrane was incubated with 1:300 dilution of rabbit monoclonal anti-p53, p38 (Cell Signaling Technologies, Beverly, Mass., USA), polyclonal anti-TGF- $\beta_{1}$, klotho antibody (Santa Cruz Bio- technology, Santa Cruz, Calif., USA), or a 1:1,000 dilution of mouse monoclonal anti-Sp1 (Santa Cruz Biotechnology), rabbit monoclonal anti-p-p38 antibody (Cell Signaling Technologies) overnight at $4{ }^{\circ} \mathrm{C}$, and then incubated with horseradish peroxidase-conjugated second antibody for $2 \mathrm{~h}$. Immunoblots were developed using an ECL Western blotting detection system (Amersham).

Reverse Transcription-Polymerase Chain Reaction (RT-PCR) Analysis for Klotho

RNA was isolated from cells using TRIzol reagent (Tiangen Biotech Co. Ltd., Beijing, China) according to the manufacturer's protocol. Total RNA was then reverse-transcribed into cDNA according to manufacturer's instructions (Fermentas). The resultant cDNA was stored at $-20^{\circ} \mathrm{C}$ until required. The oligonucleotide primers for klotho cDNA and $\beta$-actin were synthesized by Shanghai Sangon Biological Engineering Technology \& Service Co. Ltd, China. The sequence of the primers used in the PCR were as follows: klotho: sense, 5'-CAA TGG CTT CCC TCC TTT AC$3^{\prime}$ and anti-sense, $5^{\prime}$-AGC ACA GGT TTG CGT AGT CT-3'; $\beta$ actin: sense, 5'-CGT TGA CAT CCG TAA AGA C-3', and antisense, 5'-TGG AAG GTG GAC AGT GAG-3'. The reaction was conducted using the conditions as follows: denature at $94^{\circ} \mathrm{C}$ for $30 \mathrm{~s}$, anneal at $56^{\circ} \mathrm{C}$ for $30 \mathrm{~s}$, extend at $72^{\circ} \mathrm{C}$ for $1 \mathrm{~min}, 25 \mathrm{cycles}$; a final extension at $72^{\circ} \mathrm{C}$ for $10 \mathrm{~min} .10 \mu \mathrm{l}$ extended products were then electrophoresed on a $1.5 \%$ agarose gel, and the bands were visualized using a UVP high-performance ultraviolet transilluminator (UVP GOS7500, USA), the intensity of the klotho DNA bands (512 bp) was expressed as a percentage of the intensity of the $\beta$-actin bands (201 bp) with the aid of Bio-Rad Gel Doc 2000 software.

\section{Statistical Analysis}

All values are expressed as mean \pm SE. Statistical analysis was performed with one-way analysis of variance (ANOVA) and Q test. Correlation analyses were performed using Pearson's correlation. $\mathrm{p}<0.05$ was considered significantly different.

\section{Results}

\section{Immunohistochemical Detection of TGF- $\beta_{1}, p 38$, p-p38, p53 and Sp1 Protein Expression in NRK-52E Cells}

Compared with the control group, the protein expression of TGF- $\beta_{1}$, p-p38 and p53 was significantly increased in the Ang II group in NRK-52E cells; TGF- $\beta_{1}$, p-p38 and p53 protein expression in the Ang II + Fos group, Ang II + Val group, and Ang II + Fos + Val group were decreased compared to the Ang II group ( $\mathrm{p}<0.05$ ) (fig. 1A, C, D). The Sp1 protein expression in the Ang II group was significantly lower than the control group, but after the intervention of Fos and/or Val, the Spl expression reduced by Ang II was significantly increased $(p<0.05)$ (fig. 1E). There was no significant difference of TGF- $\beta_{1}, \mathrm{p}-\mathrm{p} 38$, p53 and Spl protein expression among the Ang II + Fos, Ang 

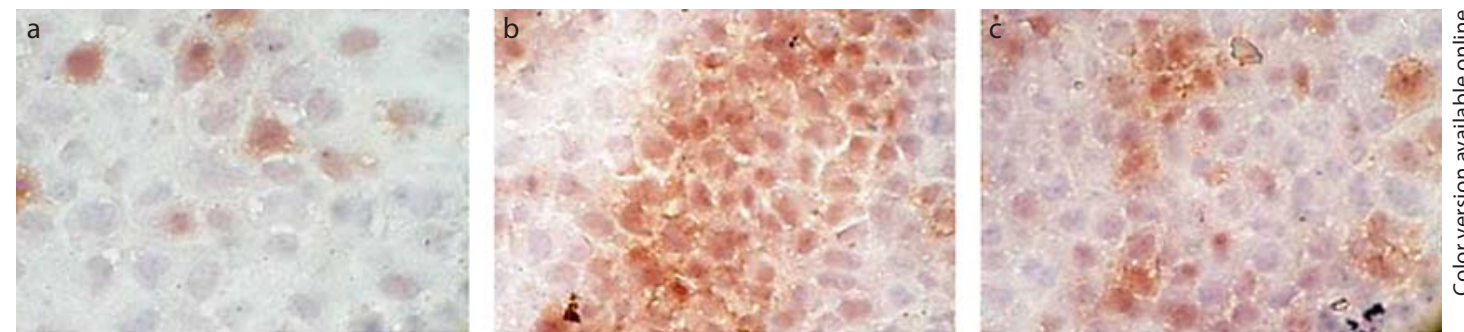

A
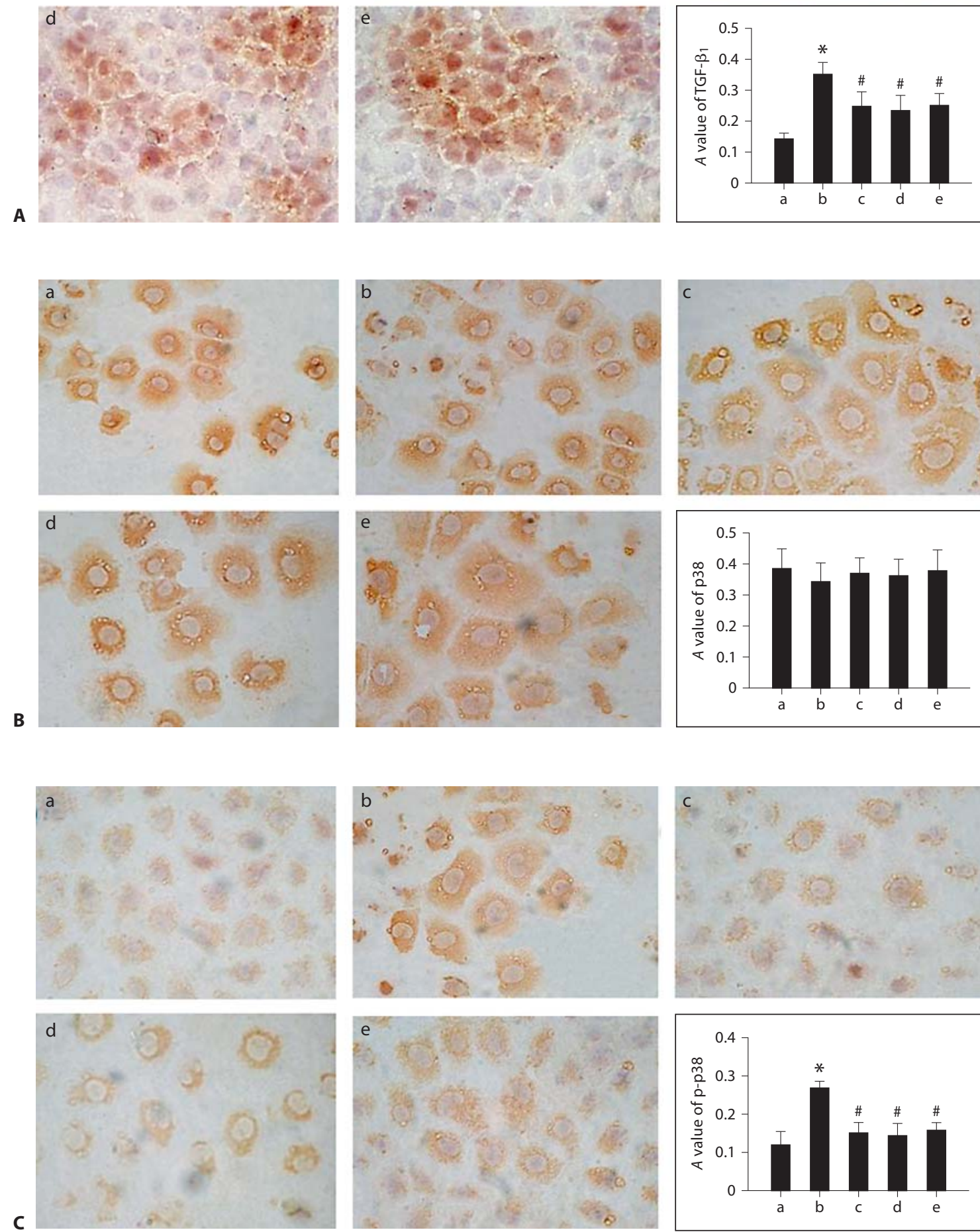

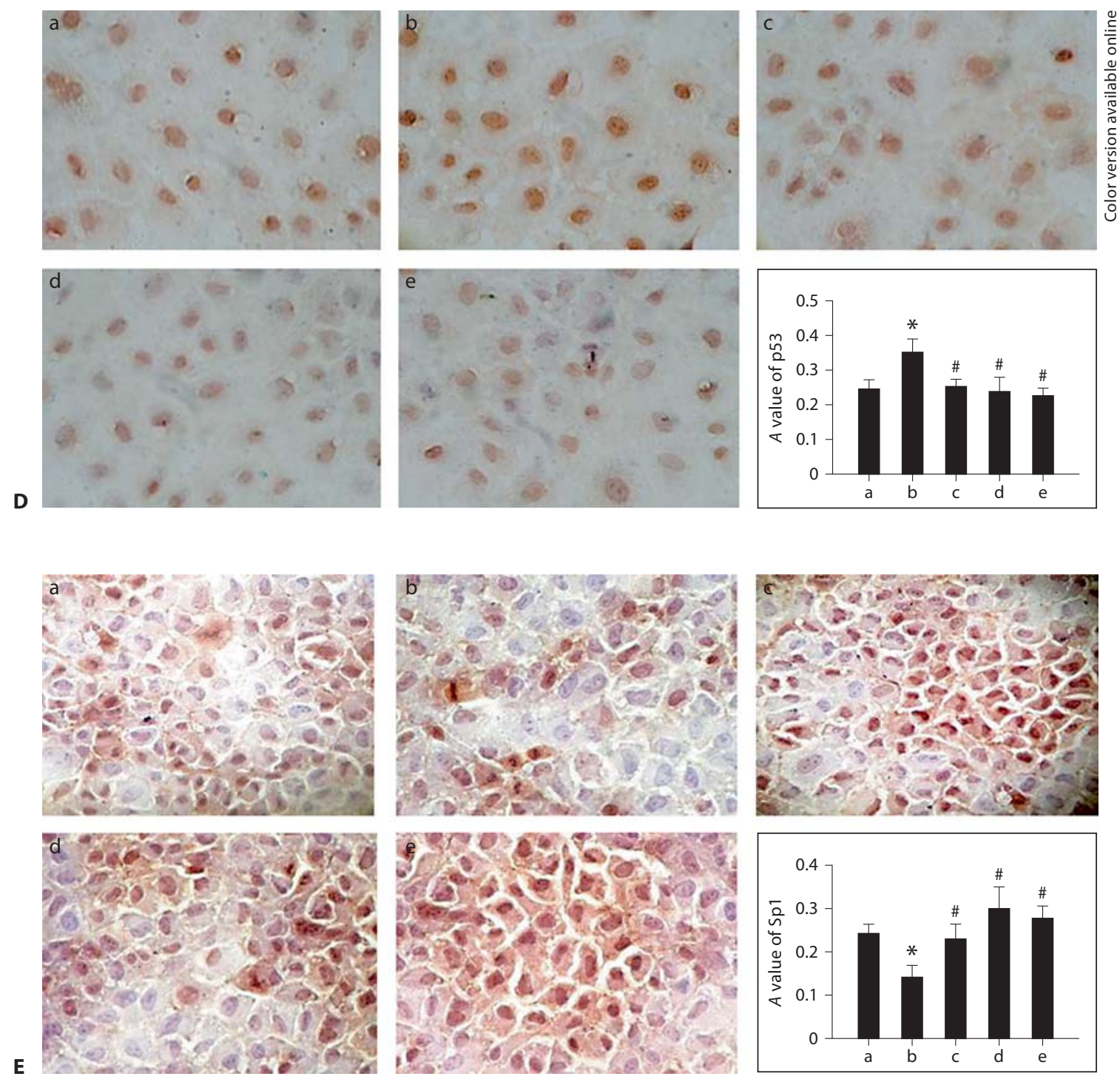

Fig. 1. Immunohistochemical detection of protein expression in different groups of NRK-52E cells (orig. magnif. $\times 400)$. A TGF- $\beta_{1}$; B p-38; C p-p38; D p53; E Sp1. a = Control group; b = Ang II group (Ang II 10 $0^{-7}$ $\mathrm{mol} / \mathrm{l}) ; \mathrm{c}=$ Ang II + Fos group (Ang II $10^{-7} \mathrm{~mol} / \mathrm{l}+$ Fos $\left.10^{-5} \mathrm{~mol} / \mathrm{l}\right) ; \mathrm{d}=$ Ang II + Val group (Ang II $10^{-7} \mathrm{~mol} / \mathrm{l}$ + Val $10^{-5} \mathrm{~mol} / \mathrm{l}$ ); e = Ang II + Fos + Val group (Ang II $10^{-7} \mathrm{~mol} / \mathrm{l}+\mathrm{Fos} 10^{-5} \mathrm{~mol} / \mathrm{l}+\mathrm{Val} 10^{-5} \mathrm{~mol} / \mathrm{l}$ ). Values are mean $\pm S E(n=5)$. ${ }^{*}$ Significantly different from the control group $(p<0.05) . ~$ Significantly different from the Ang II group ( $\mathrm{p}<0.05)$.

$\mathrm{II}+\mathrm{Val}$, and Ang II + Fos + Val groups ( $\mathrm{p}>0.05)$. There was no significant difference in $\mathrm{p} 38$ protein expression among different groups of NRK-52E cells $(p>0.05)$ (fig. 1B).

Western Blotting Detection of TGF- $\beta_{1}, p 38, p-p 38, p 53$ and Sp1 Protein Expression in NRK-52E Cells

As compared to the control group, the protein expression of TGF- $\beta_{1}, \mathrm{p}-\mathrm{p} 38$ and p53 in the Ang II group was significantly higher; Fos and/or Val treatment abrogated the Ang II-induced incremental increases in TGF- $\beta_{1}$, p-p38 and p53 protein levels $(\mathrm{p}<0.05)$. Ang II induced significantly more abundant protein expression of Sp1 than the control group; the increased abundance of Sp1 expression was abolished by Fos and/or Val treatment $(\mathrm{p}<0.05)$. There was no significant difference of the TGF- $\beta_{1}$, p-p38, p53 and Sp1 protein expression among the Ang II + Fos, Ang II + Val, and Ang II + Fos + Val 


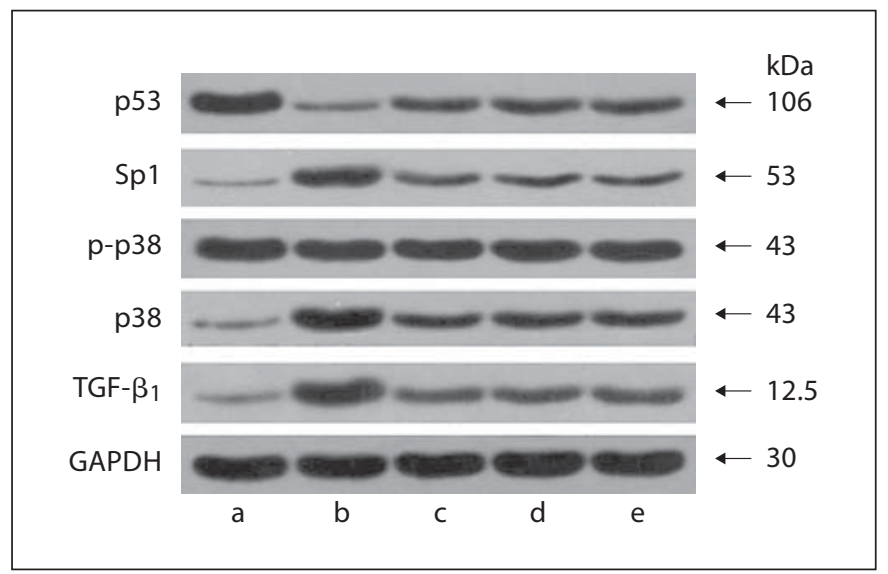

Fig. 2. Western blotting detection of Sp1, p53, p-p38, p38 and TGF- $\beta_{1}$ protein expression in different groups of NRK-52E cells. $\mathrm{a}=$ Control group; $\mathrm{b}=$ Ang II group (Ang II $\left.10^{-7} \mathrm{~mol} / \mathrm{l}\right) ; \mathrm{c}=$ Ang $\mathrm{II}+$ Fos group (Ang II $10^{-7} \mathrm{~mol} / \mathrm{l}+$ Fos $\left.10^{-5} \mathrm{~mol} / \mathrm{l}\right) ; \mathrm{d}=$ Ang II + Val group (Ang II $10^{-7} \mathrm{~mol} / \mathrm{l}+\mathrm{Val} 10^{-5} \mathrm{~mol} / \mathrm{l}$ ); e = Ang II + Fos +

groups $(\mathrm{p}>0.05)$. There was no significant difference in p38 protein expression among different groups of NRK-52E cells ( $p>0.05)$ (fig. 2).

\section{RT-PCR Analysis and Western Blotting Detection of}

Klotho mRNA and Protein Expression, Respectively, in NRK-52E Cells

The mRNA and protein expression of klotho in the control group was low, and was significantly decreased in the Ang II group; Fos and/or Val treatment relieved the reduction of klotho mRNA and protein expression by Ang II $(\mathrm{p}<0.05)$, and there was no significant difference between monotherapy and combination therapy $(p>$ 0.05) (fig. 3).

\section{Analysis of the Relationship between TGF- $\beta_{1}$ and p53 Protein Expression, Sp1 and Klotho Protein \\ Expression}

Correlation analysis showed that the protein expression of TGF- $\beta_{1}$ and $\mathrm{p} 53$ exhibited a positive linear correlation $(\mathrm{r}=0.684 ; \mathrm{p}<0.05)$; the protein expression of $\mathrm{Sp} 1$ and klotho $(\mathrm{r}=0.502 ; \mathrm{p}<0.05)$ also showed a positive linear correlation.

\section{Discussion}

In this study, we showed two major findings. First, Ang II upregulated the expression of TGF- $\beta_{1}$, p-p38 and p53, then downregulated Sp1 and klotho expression in

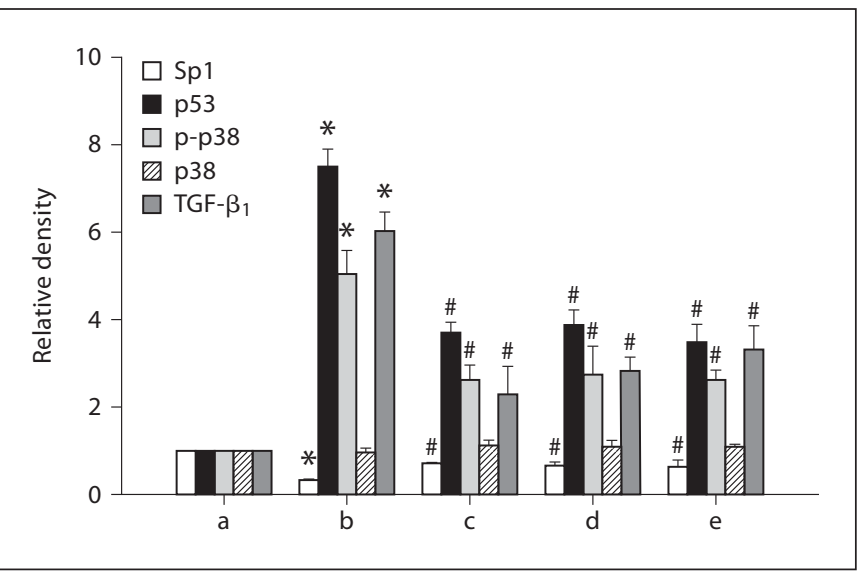

Val group (Ang II $10^{-7} \mathrm{~mol} / \mathrm{l}+$ Fos $10^{-5} \mathrm{~mol} / \mathrm{l}+\mathrm{Val} 10^{-5} \mathrm{~mol} / \mathrm{l}$ ). Values are mean $\pm S E(n=5) .{ }^{*}$ Significantly different from the control group $(\mathrm{p}<0.05)$. "Significantly different from the Ang II group $(\mathrm{p}<0.05)$.

NRK-52E cells. Second, Fos and Val had a protective role in Ang II-induced renal damage, maybe through inhibiting TGF- $\beta_{1}$, p-p38 and p53 expression, thus upregulating Spl and klotho expression.

Ang II, the main peptide of RAS, can activate mesangial cells, tubular cells and interstitial fibroblasts, increase the expression and synthesis of extracellular matrix protein and play an important role in the progression of renal disease [11]. At least some of these effects are mediated by upregulation of TGF- $\beta_{1}[12,13]$, which plays a causal role in the inflammatory changes and collagen deposition in various tissue [14-16]. It has been demonstrated that Ang II can induce upregulation of TGF- $\beta_{1}$ expression, which can activate the mitogen-activated protein kinases (MAPK) signal transduction pathway of p38 (p38MAPK) and increase p53 protein expression, resulting in organ fibrosis [17-19], some of the effects may be through AT1 receptor [20]. An elevation of Ang II-induced renal damage can be diminished by the AT1 receptor blockers [21]. All these findings suggesting that Ang II regulates the renal fibrotic process by TGF- $\beta_{1} / \mathrm{MAPK}$ signal transduction pathway and RAS blockers (ACE inhibitors and AT1 receptor blockers) can prevent the activation of the TGF$\beta_{1} /$ MAPK signal transduction pathway and renal fibrosis via blockade of Ang II action. In our study, TGF- $\beta_{1}$, p-p38 and p53 expression were upregulated by Ang II in NRK$52 \mathrm{E}$ cells, which may be one of the mechanisms involved in Ang II-induced renal damage.

Recent studies have shown that continuous infusion of Ang II downregulated renal klotho gene expression, 


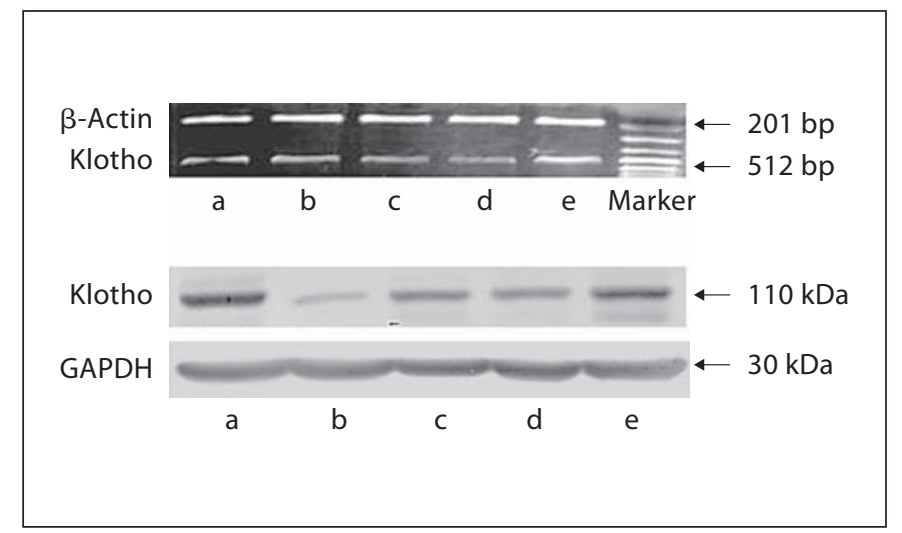

Fig. 3. Klotho mRNA and protein expression in different groups of NRK-52E cells detected by RT-PCR and Western blotting, respectively. $\mathrm{a}=$ Control group; $\mathrm{b}=$ Ang II group (Ang II 10 $\left.10^{-7} \mathrm{~mol} / \mathrm{l}\right)$; $\mathrm{c}=$ Ang II + Fos group (Ang II $10^{-7} \mathrm{~mol} / \mathrm{l}+$ Fos $10^{-5} \mathrm{~mol} / \mathrm{l}$ ) $; \mathrm{d}=$ Ang II + Val group (Ang II $\left.10^{-7} \mathrm{~mol} / \mathrm{l}+\mathrm{Val} 10^{-5} \mathrm{~mol} / \mathrm{l}\right) ; \mathrm{e}=$ Ang

which was an AT1 receptor-dependent, but non-pressordependent event. Thus, downregulation of the renal klotho gene expression may have an important role in the development of Ang II-induced renal damage [22, 23]. However, the effects and mechanisms of renal klotho expression in Ang II-induced renal damage are still unknown. According to our previous results, we chose a concentration of $10^{-7} \mathrm{~mol} / \mathrm{l}$ Ang II to intervene with NRK-52E cells to study the effects of klotho gene in Ang II-induced renal damage (data not show).

The promotor in the $5^{\prime}$ flanking region of klotho gene has been successfully cloned and sequenced. The upstream transcriptional starting site of klotho gene lacks a typical TATA or CAAT box, instead it has several binding site sequences of transcription factors such as Sp1. The finding is in concordance with the fact that $\mathrm{Spl}$ is usually located in a promotor region with no TATA box, but the function feature of these sequences is unknown yet $[24,25]$. Therefore, we propose that the Spl-binding site sequence of the upstream promotor region of klotho gene may be the only one important site needed by Sp1 to regulate klotho gene expression. As one of important transcription factors, $\mathrm{Sp} 1$ is involved in the transcription regulation of many cytokines and genes, which is closely related to $\mathrm{p} 53$ protein. It was reported that $\mathrm{p} 53$ protein could inhibit the transcription regulation activity of $\mathrm{Sp} 1$ by binding with $S p 1$ to form complexes [26,27], or by decreasing the Sp1-binding site sequence via mutation or gene knockout. Thus, Sp1 may be regulated by p53.

In this paper, we found that Ang II could upregulate the protein expression of TGF- $\beta_{1}, \mathrm{p}-\mathrm{p} 38$ and p53 in NRK-

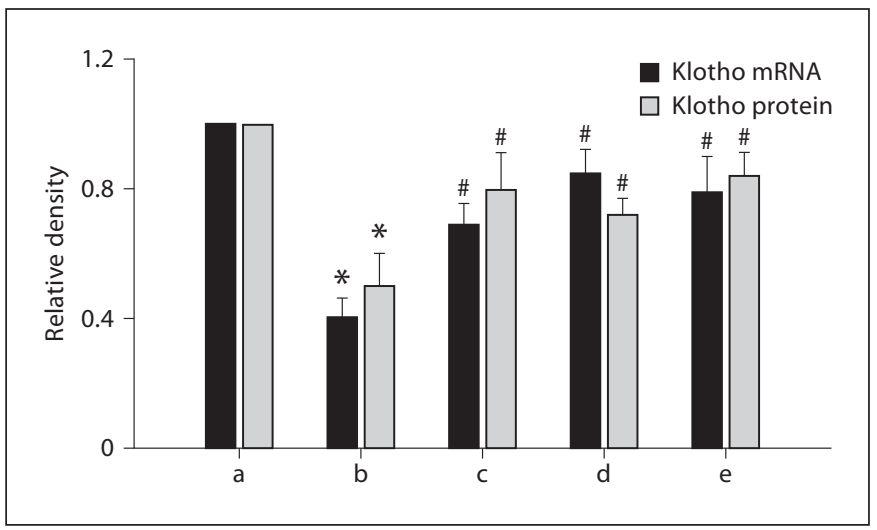

$\mathrm{II}+$ Fos + Val group (Ang II $10^{-7} \mathrm{~mol} / \mathrm{l}+\mathrm{Fos} 10^{-5} \mathrm{~mol} / \mathrm{l}+\mathrm{Val}$ $\left.10^{-5} \mathrm{~mol} / \mathrm{l}\right)$. Values are mean $\pm \mathrm{SE}(\mathrm{n}=5)$. ${ }^{*}$ Significantly different from the control group $(\mathrm{p}<0.05)$. " Significantly different from the Ang II group $(\mathrm{p}<0.05)$.

$52 \mathrm{E}$ cells, resulting in a significant inhibition of Spl and klotho expression. After the intervention of Fos and/or Val, the expression of TGF- $\beta_{1}, \mathrm{p}-\mathrm{p} 38$ and $\mathrm{p} 53$ was downregulated, while the expression of $\mathrm{Sp} 1$ and klotho gene was increased in NRK-52E cells. The protein expression of TGF- $\beta_{1}$ and 553 exhibited a positive linear correlation, indicating that $\mathrm{p} 53$ might be activated by TGF- $\beta_{1}$. In addition, Sp1 and klotho protein expression exhibited a positive linear correlation, indicating that klotho gene expression was likely to be regulated by Sp1.

One of the mechanisms involved in Ang II-induced renal damage may be as follows: Ang II induces upregulation of TGF- $\beta_{1}$ and $\mathrm{p}-\mathrm{p} 38$ expression, resulting in $\mathrm{p} 53$ activation, and then the activated p53 binds with Sp1 in the nucleus to form complexes, which will interfere with the binding of Spl and promotor of klotho gene, resulting in the inhibition of klotho expression. Fos and Val may inhibit TGF- $\beta_{1}$, p-p38 and p53 expression, thus upregulating Sp1 and klotho expression to relieve Ang II-induced renal damage. Ikushima et al. [28] found that the expression of p53/p21 in klotho gene mutant mice was obviously upregulated, while the induction of klotho gene expression could inhibit the activity of p53/p21. Integrated studies showed that there existed a mutual regulation mechanism between klotho gene and p53, which needed further investigation.

We conclude that Fos and Val have a protective role in Ang II-induced renal damage, and it may be through inhibiting TGF- $\beta_{1}, \mathrm{p}-\mathrm{p} 38$ and p53 expression, thus upregulating Sp1 and klotho gene expression. 


\section{References}

$\checkmark 1$ Kuro-o M, Matsumura Y, Aizawa H, et al: Mutation of the mouse klotho gene leads to a syndrome resembling aging. Nature 1997; 390:45-51.

-2 Masuda H, Chikuda H, Suga T, et al: Regulation of multiple ageing-like phenotypes by inducible klotho gene expression in klotho mutant mice. Mech Ageing Dev 2005;126: 1274-1283.

-3 Wang Y, Sun Z: Klotho gene delivery prevents the progression of spontaneous hypertension and renal damage. Hypertension 2009;54:810-817.

4 Sugiura H, Yoshida T, Mitobe M, et al: Klotho reduces apoptosis in experimental ischaemic acute kidney injury via HSP-70. Nephrol Dial Transplant 2010;25:60-68.

$\checkmark 5$ Haruna Y, Kashihara N, Satoh M, et al: Amelioration of progressive renal injury by genetic manipulation of klotho gene. Proc Natl Acad Sci USA 2007;104:2331-2336.

6 Yahata K, Mori K, Arai H, et al: Molecular cloning and expression of a novel klotho-related protein. J Mol Med 2000;78:389-394.

$\checkmark 7$ Koh N, Fujimori T, Nishiguchi S, et al: Severely reduced production of klotho in human chronic renal failure kidney. Biochem Biophys Res Commun 2001;280:1015-1020.

$\checkmark 8$ Negri AL: The klotho gene: a gene predominantly expressed in the kidney is a fundamental regulator of aging and calcium/phosphorus metabolism. J Nephrol 2005; 18: 654-658.

-9 Siamopoulos KC, Kalaitzidis RG: Inhibition of the renin-angiotensin system and chronic kidney disease. Int Urol Nephrol 2008;40: 1015-1025.

10 Macconi D: Targeting the renin angiotensin system for remission/regression of chronic kidney disease. Histol Histopathol 2010;25: 655-668.
11 Ruiz-Ortega M, Ruperez M, Esteban V, et al Angiotensin II: a key factor in the inflammatory and fibrotic response in kidney diseases. Nephrol Dial Transplant 2006;21:16-20.

12 Yang F, Chung AC, Huang XR, et al: Angiotensin II induces connective tissue growth factor and collagen I expression via transforming growth factor- $\beta$-dependent and -independent Smad pathways: the role of Smad3. Hypertension 2009;54:877-884.

13 Rosón MI, Cao G, Della Penna S, et al: Angiotensin II increases intrarenal transforming growth factor- $\beta_{1}$ in rats submitted to sodium overload independently of blood pressure. Hypertens Res 2008;31:707-715.

14 Mirshafiey A, Mohsenzadegan M: TGF- $\beta$ as a promising option in the treatment of multiple sclerosis. Neuropharmacology 2009;56: 929-936.

15 Gao X, He X, Luo B, et al: Angiotensin II in creases collagen I expression via transforming growth factor- $\beta_{1}$ and extracellular signal-regulated kinase in cardiac fibroblasts. Eur J Pharmacol 2009;606:115-120.

16 Gauldie J, Bonniaud P, Sime P, et al: TGF- $\beta$, Smad 3 and the process of progressive fibrosis. Biochem Soc Trans 2007;35:661-664.

-17 Brezniceanu ML, Wei CC, Zhang SL, et al: Transforming growth factor- $\beta_{1}$ stimulates angiotensinogen gene expression in kidney proximal tubular cells. Kidney Int 2006;69: 1977-1985.

-18 Takekawa M, Tatebayashi K, Itoh F, et al: Smad-dependent GADD $45 \beta$ expression mediates delayed activation of p38 MAP kinase by TGF- $\beta$. EMBO J 2002;21:6473-6482.

$\checkmark 19$ Viedt C, Soto U, Krieger-Brauer HI, et al: Differential activation of mitogen-activated protein kinases in smooth muscle cells by angiotensin II: involvement of p22phox and reactive oxygen species. Arterioscler Thromb Vasc Biol 2000;20:940-948.
20 Vaziri ND, Bai Y, Ni Z, et al: Intra-renal angiotensin II/AT1 receptor, oxidative stress, inflammation, and progressive injury in renal mass reduction J Pharmacol Exp Ther 2007;323:85-93.

21 Pan Q, Yang XH, Cheng YX: Angiotensin II stimulates MCP-1 production in rat glomerular endothelial cells via NAD(P)H oxidasedependent nuclear factor- $\mathrm{\kappa B}$ signaling. Braz J Med Biol Res 2009;42:531-536.

22 Ishizaka N, Mitani H, Nagai R: Angiotensin II regulates klotho gene expression. Nippon Rinsho 2002;60:1935-1939.

23 Mitani H, Ishizaka N, Aizawa T, et al: In vivo klotho gene transfer ameliorates angiotensin II-induced renal damage. Hypertension 2002;39:838-843.

24 Shiraki-Iida T, Aizawa H, Matsumura Y, et al: Structure of the mouse klotho gene and its two transcripts encoding membrane and secreted protein. FEBS Lett 1998;424:6-10.

25 Matsumura Y, Aizawa H, Shiraki-Iida T, et al: Identification of the human klotho gene and its two transcripts encoding membrane and secreted klotho protein. Biochem Biophys Res Commun 1998;242:626-630.

26 Yamabe Y, Shimaoto A, Goto M, et al: Splmediated transcription of the Werner helicase gene is modulated by $\mathrm{Rb}$ and p53. Mol Cell Biol 1998;18:6191-6200.

27 Zhan M, Yu Dihua, Liu J, et al: Transcription repression of protein kinase $\mathrm{C} \alpha$ via $\mathrm{Sp} 1$ by wild-type p53 is involved in inhibition of multidrug resistance $1 \mathrm{P}$-glycoprotein phosphorylation. J Biol Chem 2005;280:48254833.

28 Ikushima M, Rakugi H, Ishikawa K, et al: Anti-apoptotic andante-senescene effects of klotho on vascular endothelial cells. Biochem Biophys Res Commun 2006;339:827832. 